\title{
PERFORMANCE OF MAIZE-SOYBEAN INTERCROP COMBINATION IN THE TROPICS: RESULTS OF A MULTI-LOCATION STUDY
}

\author{
S. AHMED' and M.R. RAO \\ ${ }^{1}$ Resource Systems Institute, East-West Center, 1777 East-West Road, Honolulu, HI 96848 \\ (U.S.A.) \\ IInternational Crops Research Institute for the Semi-Arid Tropics (ICRISAT), Patancheru \\ P.O. 502 324, Andhra Pradesh (India)
}

(Accepted 17 December 1981)

\section{ABSTRACT}

Ahmed, S. and Rao, M.R., 1982. Performance of maize-soybean intercrop combination in the tropics: results of a multi-location study. Field Crops Res., 5: 147-161.

Results of an experiment conducted at 14 locations in seven countries during 1976-79 under the coordination of the East-West Center, Hawaii, are discussed. This study compares the performance of maize-soybean intercrop with the component sole crops at different $\mathrm{N}$ levels applied to maize. Intercropping generally gave greater combined yields and monetary returns than obtained from either crop grown alone. On the basis of land equivalent ratio, yield advantage from intercropping varied from $64 \%$ at zero $\mathrm{N}$ to $42 \%$ at $100 \%$ of the recommended rate of $\mathrm{N}$ application to maize. Returns from intercropping at zero nitrogen were $61 \%$ higher than sole maize and $44 \%$ higher than sole soybean. Maize-soybean intercrop appears to be particularly well-suited for small farmers in developing countries who operate at subsistence level and use little or no fertilizer. Increased research effort is suggested to identify other crop combinations for use under various ecosystems and management levels, develop efficient methods of fertilising the cereal and to understand benefits of legumes in intercropping.

\section{INTRODUCTION}

Growing two or more crops together, either broadcast (mixed cropping) or in rows (intercropping), is a traditional system widely practiced in the rainfed areas of the tropics. Small farmers have often shown preference for this system as it provides an opportunity to grow diverse crops, reduces risks of total crop failure in unfavourable seasons, and employs family labour more gainfully. Research on intercropping, however, did not receive much attention in the past as the practice was thought to be suited only to underdeveloped situations, and would be replaced gradually by sole cropping as agricultural development occurred. Though this was true to a certain extent (Norman, 1974; Jodha, 1976), the phenomenal improvement in sole crop technology has not yet displaced intercropping, and the latter continues to be important in many countries. The recent research on intercropping has confirmed what 


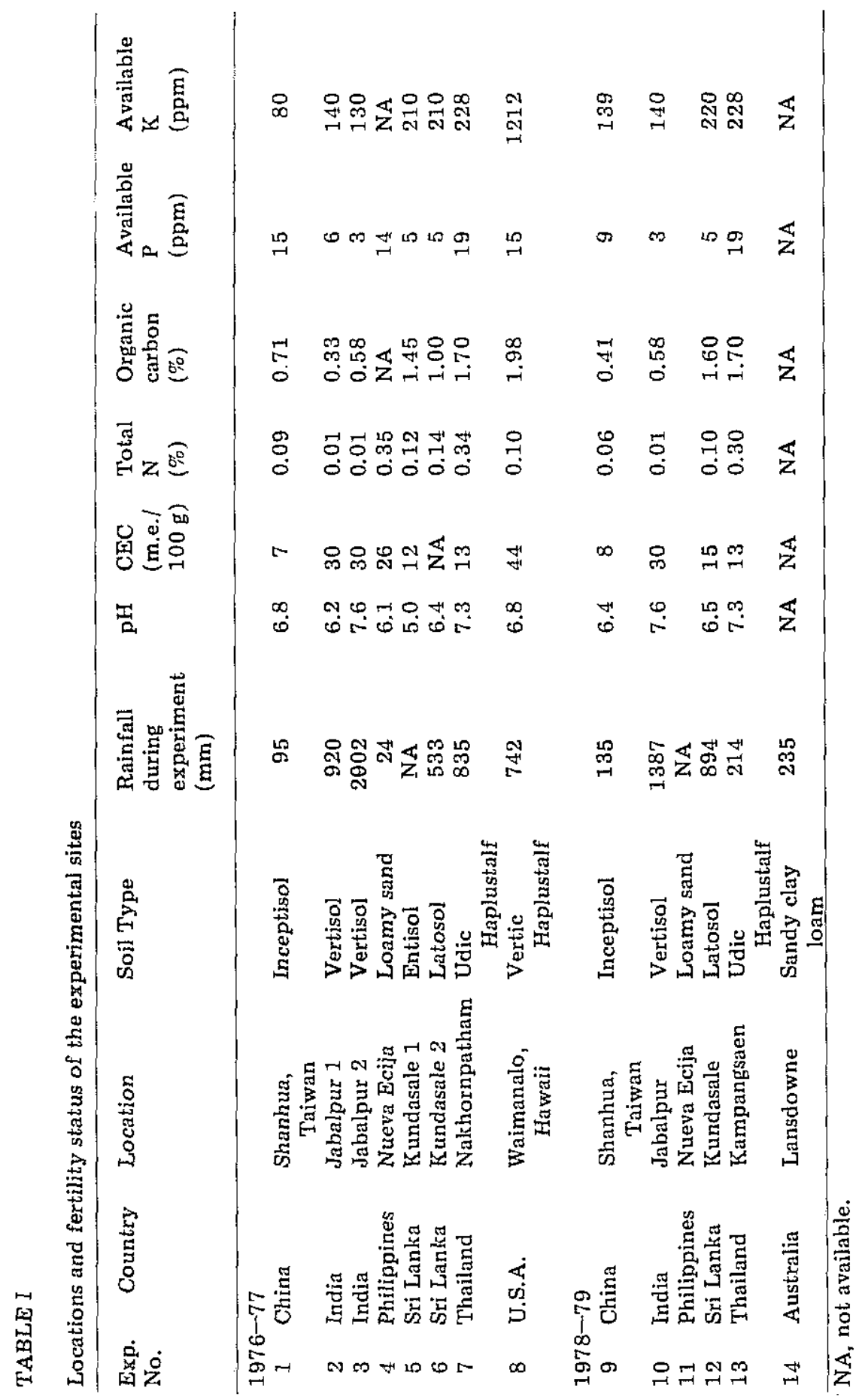


small farmers in developing countries have known for a long time, namely, that intercropping makes efficient use of resources and generally provides a yield advantage compared to sole cropping (Willey, 1979). The advantage was as much as $50-80 \%$ from intercropping of long season crops such as pigeonpea and castor with cereals or pulses (Saxena and Yadav, 1975; Spratt and Chowdhury, 1978) and $25-40 \%$ in combinations of maize or sorghum with low canopy legumes (Willey and Osiru, 1972; Tiwari and Bisen, 1975; Wahua and Miller, 1978; De et al., 1978). Legumes were found to have particular significance in intercropping because of the potential of nitrogen transfer to the subsequent cereal crops (Jones, 1974; Lal et al., 1978; Giri and De, 1979). A few studies have also indicated the current season benefit of legume to the associated cereal (Virtanen et al., 1937; Ruschel et al., 1979). The above findings have highlighted that one way to enhance agricultural production in rainfed tropical areas is through increased work on intercropping in a more organized and multidisciplinary approach.

-In view of the above, cereal-legume intercrop studies were included as part of a coordinated, 5-year international agronomic research project entitled Increasing Productivity Under Tight Supplies (INPUTS) that was initiated by the East-West Center in 1974, in collaboration with several national and international research organizations in the Asia and Pacific region (Ahmed, 1974). Initial studies during 1975-76 showed that intercropping maize with soybean, cowpea or mungbean was more profitable than growing either crop alone (Ahmed and Gunasena, 1979). Encouraged by these results, further experiments were conducted during $1976-77$ and $1978-79$ to evaluate the advantage of intercropping of maize with low canopy legumes at different levels of nitrogen. This paper summarises the results of maize-soybean combination which formed a part of this intercrop comparisons.

\section{MATERIALS AND METHODS}

Details of locations and the experimental sites are given in Table I. The 1976-77 experiment had six 'core' treatments: sole maize at three nitrogen levels, maize--soybean intercrop at two nitrogen levels and sole soybean without any nitrogen application (Gunasena et al., 1978). Some "optional" treatments were included to enable the cooperators examine additional legumes and practices of local importance. Since agroclimatic conditions and cultivars used varied across locations, $\mathrm{N}$ rates required for studying yield response also varied. To enable comparison of results across locations, therefore, the strategy adopted was to select nitrogen levels at each location as percentages of the locally recommended $\mathrm{N}$ rate for maize for that location (Ahmed, 1974). The actual amount of $\mathrm{N}$ applied at the $100 \% \mathrm{~N}$ level ranged from 50 to $120 \mathrm{~kg} \mathrm{~N} / \mathrm{ha}$ (Table II). Sole maize received 0, 50 and $100 \% \mathrm{~N}$ levels, while maize in intercrop received the first two levels only. Half of the nitrogen was applied basally, and the remainder, about a month later after thinning and weeding. In all cases, this was applied by the side of the maize plants. All plots 


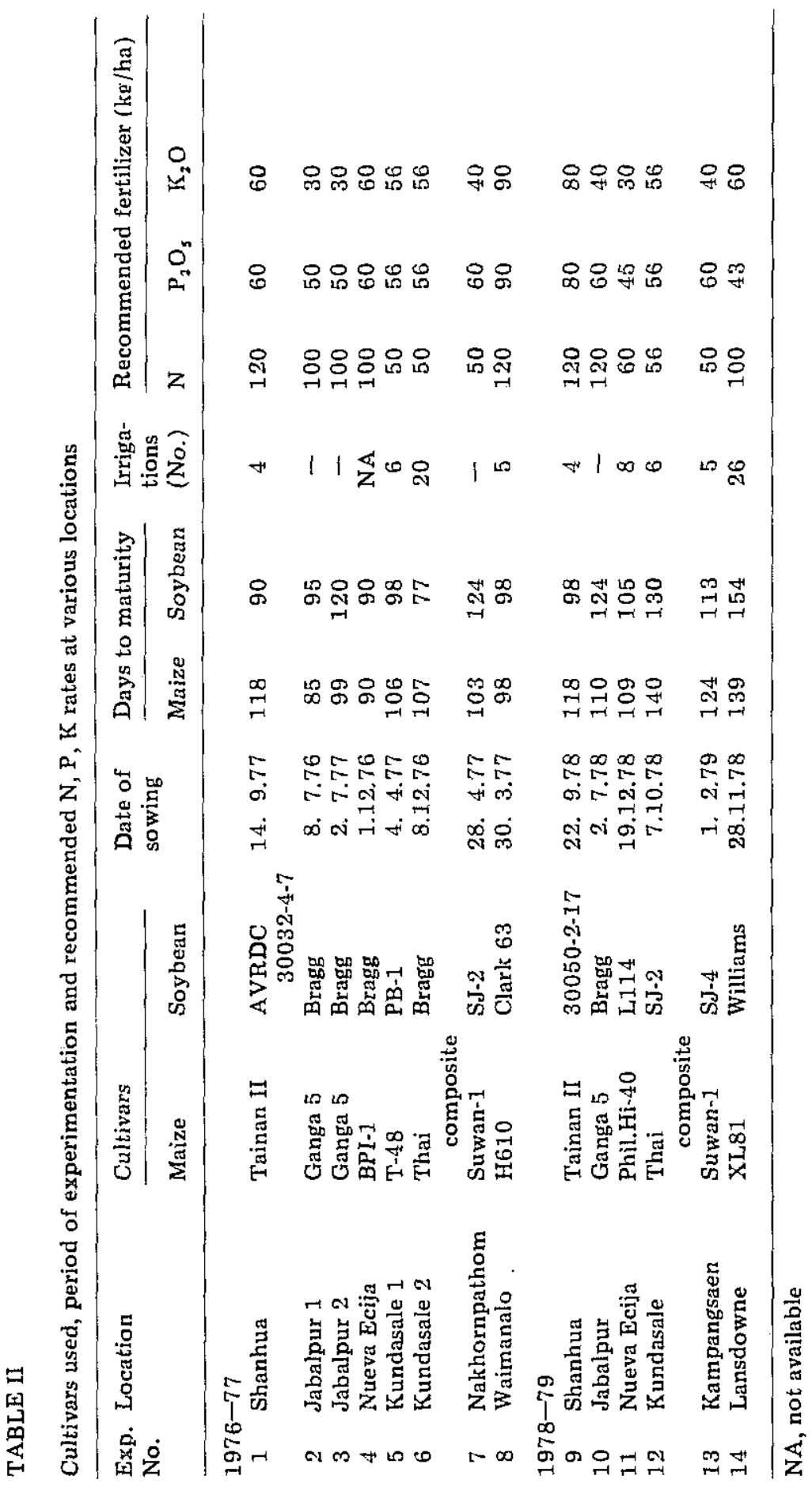


received a uniform basal application of $\mathrm{P}$ and $\mathrm{K}$ according to the local recommendation. The treatments were replicated thrice in a randomised block design. The experiment was modified in 1978-79 to include four levels of nitrogen $(0,25,50$ and $100 \%$ of the locally recommended rate for maize) applied to maize in both sole and intercropping systems (Rao et al., 1979). Sole soy bean without nitrogen made up the ninth "core" treatment. This experiment was also conducted in a randomised block design with four replications; trials in India and Thailand, however, had only three each.

Plant spacing for sole crops was: (1) maize: $100 \times 25 \mathrm{~cm}(1976-77)$ and $100 \times 20 \mathrm{~cm}(1978-79)$; and (2) soybean: $50 \times 5 \mathrm{~cm}$. The intercrop was planted at an arrangement of 1 maize row: 2 soybean rows using the same row and within row spacings as in the respective sole systems for both crops (Fig. 1). Thus the intercrop had $200 \%$ population ( $100 \%$ of each crop).

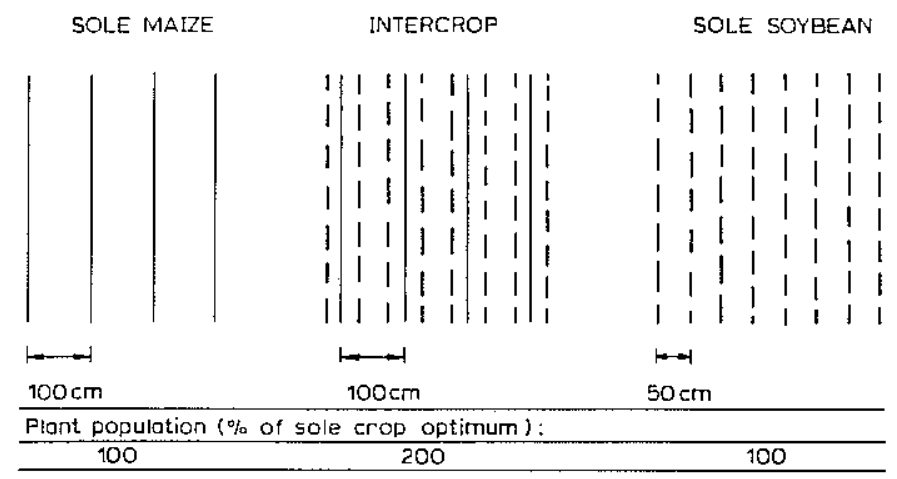

Fig. 1. Planting pattern in sole and intercrop system.

Cooperators were advised to inoculate soybean but information on this was not fully available. Crops were hand-sown, and in intercropping both crops were planted at the same time. Plot size in both years was $4 \mathrm{~m} \times 7 \mathrm{~m}$ with four rows of maize and/or eight rows of soybean. In 1976-77, $5 \mathrm{~m}$ of the two middle rows of maize and/or of the four middle rows of soybean were harvested for yield estimation; $6 \mathrm{~m}$ were harvested in 1978-79. The crops were weeded and sprayed against insects whenever necessary. Irrigation was given during period of stress except at Jabalpur (India) and Nakhornpathom (Thailand) where crops matured on rainfall alone. Details of cultivars, and planting and harvest times at each location are given in Table II.

Intercrop performance was evaluated by considering the yield of each crop, land equivalent ratios (LER) and economic returns; LER is defined as the sum of the relative land areas required by sole crops to produce the same yields as obtained from intercropping. This expresses intercrop yields on a relative basis to the sole crops (i.e. 1.00) and provides a truer measure of physiological advantage of intercropping (Willey, 1979). Monetary returns from sole and intercropping at different nitrogen levels were calculated using local market prices for maize and soybean after deducting the variable cost of nitrogen fertilizer. 


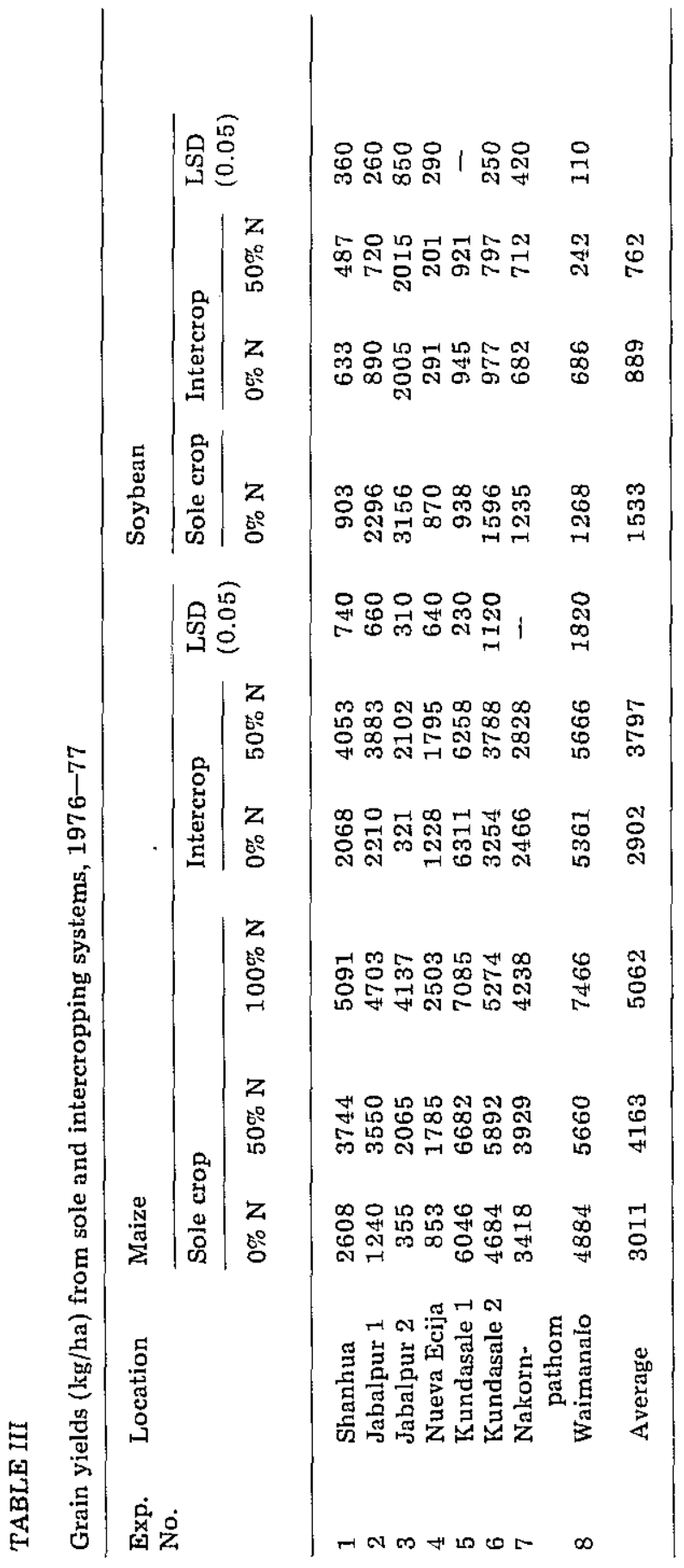


Maize and soybean grain yields obtained from the 1976-77 and 1978-79 ex. periments are indicated in Table III and IV, respectively. Yields of both crops varied markedly over sites. This is understandable as these experiments were conducted at different geographical locations having wide variations in agroclimatic conditions and in management practices (Table I and II).

\section{Sole maize yields}

Sole maize yield in the zero- $N$ plots ranged from less than $0.2 \mathrm{t} / \mathrm{ha}$ (Exp. 10) to about $9 \mathrm{t} / \mathrm{ha}$ (Exp.14). The yield obtained in each of the locations at zero $\mathrm{N}$ to some extent reflected the inherent soil fertility status (Table I). Maize yields without nitrogen application were consistently poor in India, moderate in Thailand and Taiwan and high in Hawaii and Australia. Yields were good in one of the years in Sri Lanka and Philippines but poor in the other year perhaps because of unfavourable conditions.

The average response of sole maize to the first $50 \% \mathrm{~N}$ was maximum at $337 \%$ in India (Exps. 2, 3 and 10). This was followed by $102 \%$ response in the Philippines (Exps. 4 and 11), 59\% in Taiwan (Exps. 1 and 9), 26\% in Sri Lanka (Exps. 5, 6 and 12) and 18\% in Thailand (Exps. 7 and 13). The second 50\% of the total $100 \% \mathrm{~N}$ resulted in a decreased level of response, the maximum again being in India (56\%), followed by $32 \%$ in Hawaii and $20 \%$ in Taiwan. At other locations the response was low or non-existent. Thus the sites which gave the poorest maize yield without $\mathrm{N}$ exhibited the highest response to $\mathrm{N}$ application and the vice versa. The pattern of response appeared to be curvilinear at most of the locations (Table III and Appendix I) indicating that the amount of $\mathrm{N}$ applied at $100 \%$ level appropriately represented the optimum level.

\section{Intercropped maize yields}

When maize was not fertilized with nitrogen, yields between sole and intercropping were similar at most locations. Intercrop maize yields were significantly higher than in sole cropping only in three experiments (Exps. 2, 5 and 12). But they were significantly lower than those of sole crop in equal number of cases (Exps. 6, 7 and 13). Therefore, results of these experiments do not give much support to the belief that grain legumes in intercropping might benefit the associated cereal during the growing season. This is true considering that the beneficial effect of soybean was not consistent over years at a location (Exps. 2, 3 and 10) and between experiments conducted at the same location within a year (Exps. 5 and 6). Similar results were reported by a few other workers (Agboola and Fayemi, 1970; IRRI, 1976; Ahmed and Gunasena, 1979). In view of the mixed results, more detailed studies would be necessary using Rhizobium inoculation and sophisticated methods of analyses for understanding the current season benefits of legumes in intercropping. 
TABLE IV

Grain yields ( $\mathrm{kg} / \mathrm{ha}$ ) from sole and intercxopping systems, 1978-79

\begin{tabular}{|c|c|c|c|c|c|c|c|c|c|}
\hline \multirow{3}{*}{$\begin{array}{l}\text { Exp. } \\
\text { No. }\end{array}$} & \multirow[t]{3}{*}{ Location } & \multicolumn{8}{|l|}{ Maize } \\
\hline & & \multicolumn{4}{|l|}{ Sole } & \multicolumn{4}{|c|}{ Intercrop } \\
\hline & & $0 \% \mathrm{~N}$ & $25 \% \mathrm{~N}$ & $50 \% \mathrm{~N}$ & $100 \% \mathrm{~N}$ & $0 \% \mathrm{~N}$ & $25 \% N$ & $50 \% \mathrm{~N}$ & $100 \% \mathrm{~N}$ \\
\hline 9 & Shanhua & 3557 & 5519 & 6069 & 6678 & 3765 & 5009 & 5147 & 6147 \\
\hline 10 & Jabalpur & 147 & 1044 & 1988 & 3008 & 170 & 1097 & 2092 & 2711 \\
\hline 11 & Nueva Ecija & 2135 & 2649 & 4263 & 4163 & 2612 & 2946 & 4050 & 4355 \\
\hline 12 & Kundasale & 1296 & 2219 & 2619 & 2722 & 1697 & 1893 & 2195 & 2502 \\
\hline 13 & Kampangsaen & n3448 & 4022 & 4153 & 4933 & 2215 & 2267 & 2478 & 3153 \\
\hline \multirow[t]{2}{*}{14} & Lansdowne & 6680 & 8531 & 8604 & 8941 & 7566 & 6917 & 6507 & 7477 \\
\hline & Average & 2875 & 3997 & 4616 & 5074 & 3004 & 3355 & 3745 & 4390 \\
\hline
\end{tabular}

Intercropped maize generally responded to nitrogen in the same pattern as the sole crop which indicates that whatever effect the legume had was more or less similar at all levels of $\mathrm{N}$ application. The response pattern was, however, some what different in Taiwan and Sri Lanka in 1978-79, where the sole maize response was curvilinear while that of intercropped maize tended to be linear (see Appendix). In nine out of 14 trials, there were no significant differences in maize yields between sole and intercropping. Sole maize yields were significantly greater than intercropped maize at all $\mathrm{N}$ levels in both trials in Thailand (Exps. 7 and 13) and one experiment in Taiwan (Exp. 9), and at $50 \% \mathrm{~N}$ level in all the three experiments in Sri Lanka (5, 6 and 12). Spatial competition with soybean may possibly be the main reason for the decreased maize yield in intercropping, although competition for the applied $\mathrm{N}$ may also be a factor in some cases. Over the two years, intercrop maize yields averaged $100 \%, 84 \%, 87 \%$ and $86 \%$ of sole maize at $0,25,50$ and $100 \%$ recommended rates of nitrogen respectively. That means maize was able to utilise applied nitrogen better under sole cropping than in intercropping.

\section{Soybean yields}

Sole soybean yield ranged from $0.9 \mathrm{t} / \mathrm{ha}$ in Taiwan and Philippines (Exps. 1 and 4) to over 3.0 t/ha in India (Exps. 3 and 10). Consistently high yields in India despite poor maize performance suggests that soybean nodulated and adapted very well over there. It also produced good yields in Australia and moderate yields around $1250 \mathrm{~kg} / \mathrm{ha}$ in Thailand and Hawaii. Yields at other places were low in 1976-77 perhaps due to poor nodulation but considerably improved in 1978-79 due to favourable season.

At practically all locations, soybean yields were reduced significantly by intercropping with maize, the decrease ranging from 27\% (Exp.9) to $80 \%$ 


\begin{tabular}{|c|c|c|c|c|c|c|c|c|}
\hline \multirow{2}{*}{\multicolumn{3}{|c|}{$\operatorname{LSD}(0.05)$}} & \multicolumn{6}{|c|}{ Soybean } \\
\hline & & & \multirow{2}{*}{$\frac{\text { Sole }}{0 \% \mathrm{~N}}$} & \multicolumn{4}{|c|}{ Intercropped } & \multirow{2}{*}{$\begin{array}{l}\text { LSD } \\
(0.05)\end{array}$} \\
\hline $\begin{array}{l}\mathrm{N} \\
\text { levels }\end{array}$ & $\begin{array}{l}\text { Sole vs } \\
\text { inter- } \\
\text { crop }\end{array}$ & $\begin{array}{l}\mathrm{N} \text { vs } \\
\text { systems }\end{array}$ & & $0 \% \mathrm{~N}$ & $25 \% \mathrm{~N}$ & $50 \% \mathrm{~N}$ & $100 \% \mathrm{~N}$ & \\
\hline 316 & 223 & 446 & 2289 & 1668 & 1298 & 1199 & 1378 & 309 \\
\hline 197 & - & - & 3383 & 2102 & 1708 & 1783 & 1850 & 335 \\
\hline 825 & - & - & 1241 & 496 & 387 & 275 & 251 & 178 \\
\hline 232 & - & 380 & 1817 & 899 & 1378 & 1242 & 1290 & 230 \\
\hline 335 & 290 & - & 1285 & 880 & 1154 & 1032 & 1068 & 121 \\
\hline- & - & - & 2677 & 534 & 565 & 570 & 533 & 490 \\
\hline- & - & - & 2115 & 1096 & 1082 & 1016 & 1061 & \\
\hline
\end{tabular}

(Exp. 14). The only exception was an experiment in Sri Lanka (Exp. 5) where yields were more or less the same as under sole cropping. The decreased soybean yield due to intercropping is probably due to the shading effect of maize (Syariffuddin et al., 1974; IRRI, 1976). This is supported by the fact that in eight of the 14 experiments $(1,2,4,6,8-11)$, while maize yields increased with fertilizer application in intercropping, yields of the corresponding intercropped soybean decreased. In two cases (Exps. 5 and 14) where maize yields were unaffected due to fertilizer, soybean yield also remained the same. However, in one experiment although maize yields increased with nitrogen, soybean yield was unaffected (Exp. 3). In three other experiments ( 7,12 and 13), soybean yield increased with $\mathrm{N}$ application along with increase in maize yield. This discrepancy is difficult to explain. The response of soybean in the latter three situations could partly be due to inadequate nodulation, thus it benefitted from the nitrogen applied to maize in intercropping.

\section{Intercropping efficiency}

The land equivalent ratios (LER's) obtained from the 1976-77 and 197879 experiments are recorded in Table V. Intercropping of maize and soybean was more productive than growing them separately, as can be gauged from the total LER values which were greater than 1.0 at all locations and at all $\mathrm{N}$ levels, except in Australia (Exp. 14). The magnitude of intercropping advantage observed at some of locations appears to be particularly good considering that the temporal difference between the component crops was only 3 to 4 weeks (Table II). The highest LER values were generally found at $0 \%$ $\mathrm{N}$ level. This was because intercropped maize at this $\mathrm{N}$ level generally yielded either more than, or the same as, the corresponding sole maize (Tables III and IV). LER values averaged 1.64 at $0 \% \mathrm{~N}$ and progressively decreased with in- 
TABLE V

Land equivalent ratios (LER) of maize-soybean intercropping system at different levels of nitrogen fertility

\begin{tabular}{|c|c|c|c|c|c|c|}
\hline \multirow[t]{2}{*}{ Exp. No. } & \multirow[t]{2}{*}{ Location } & \multicolumn{4}{|c|}{ Nitrogen as $\%$ of recommended rate } & \multirow{2}{*}{$\begin{array}{c}\operatorname{LSD}^{\mathrm{A}} \\
(0.05)\end{array}$} \\
\hline & & $0 \%$ & $25 \%$ & $50 \%$ & $100 \%$ & \\
\hline 1 & Shanhua & 1.49 & & 1.62 & & 0.26 \\
\hline 2 & Jabalpur 1 & 2.17 & & 1.40 & & 0.28 \\
\hline 3 & Jabalpur 2 & 1.53 & & 1.66 & & 0.41 \\
\hline 4 & Nueva Ecija & 1.77 & & 1.23 & & 0.41 \\
\hline 5 & Kundasale 1 & 2.04 & & 2.01 & & 0.05 \\
\hline 6 & Kundasale 2 & 1.30 & & 1.19 & & - \\
\hline 7 & Nakornpathom & 1.27 & & 1.30 & & - \\
\hline \multirow[t]{2}{*}{8} & Waimanalo & 1.64 & & 1.19 & & 0.31 \\
\hline & Mean & 1.65 & & 1.45 & & \\
\hline 9 & Shanhua & 1.79 & 1.49 & 1.37 & 1.52 & 0.15 \\
\hline 10 & Jabalpur & 1.78 & 1.56 & 1.57 & 1.45 & 0.37 \\
\hline 11 & Nueva Ecija & 1.64 & 1.42 & 1.19 & 1.35 & - \\
\hline 12 & Kundasale & 1.80 & 1.61 & 1.52 & 1.66 & 0.29 \\
\hline 13 & Kampangsaen & 1.33 & 1.46 & 1.40 & 1.47 & 0.18 \\
\hline \multirow[t]{2}{*}{14} & Lansdowne & 1.36 & 1.03 & 1.01 & 1.09 & - \\
\hline & Mean & 1.62 & 1.43 & 1.34 & 1.42 & - \\
\hline
\end{tabular}

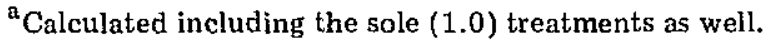

creasing $\mathrm{N}$ rates to 1.42 at $100 \% \mathrm{~N}$. This indicates the greater advantage of maize-soybean intercropping when little or no fertilizer is applied.

$\checkmark$ This trend apparently gives credence to the belief that intercropping is less advantageous at higher fertility. It should, however, be pointed out that absolute yields increased with fertilizer, so although the relative advantage decreased, the absolute value of the advantage was much higher at high fertility. Considering the fact that the fertility status of research farms is usually much higher than that of real-farm situations, particularly in developing countries, results of the current study indicate that intercropping of maize and soybean may provide significant advantages under a wide range of environments.

Advantage of intercropping usually results from the complementary use of growth resources over time and space. The combined intercrop canopy or root systems may make greater and/or more efficient use of light, water and nutrients than the component sole crops (Natarajan and Wiley, 1980; Wiley, 1979). As no measurements were made on resource use in the present experiments, it is not possible to quantitatively identify a particular resource use which might have contributed to the intercrop advantage. Water was not a limiting resource as practically all crops were irrigated periodically. Maize 
yield in intercropping was $90 \%$ or more compared to its yield in sole cropping in the majority of cases, and soybean yield was additive. Thus, the intercropping advantage depended mostly on soybean yield. The proximity of crops in intercropping suggests a close intermingling of root systems which might result in a greater exploitation of available nutrients. The increased soybean yield in intercropping at higher $\mathrm{N}$ levels of some locations may possibly reflect this. However, efficient use of light by the combined intercrop canopy, reported particularly for the combinations of $\mathrm{C} 4$ (maize) and C3 (soybean) crops, might also have been an important factor responsible for higher advantage (Trenbath, 1974; Willey, 1979). Several other investigators also reported substantial advantage from intercropping systems of maize or sorghum with soybean or other similar low-canopy legumes (Willey and Osiru, 1972; IRRI, 1976; Ahmed and Gunasena, 1979). However, no advantage was observed in situations like Australia where a vigorous and competitive cereal completely dominated the legume.

\section{Monetary returns}

The total economic value of the produce in different treatments is indicated in Tables VI and VII for 1976-77 and 1978-79 data, respectively. It shculd be emphasized that all generalizations presented here apply at the crop

\section{TABLE VI}

Monetary returns (US $\$ /$ ha) from sole and intercrop systems of maize and soybean, 1976-77

Location/Exp. No.

Tainan Jabalpur $\begin{aligned} & \text { Nueva- Kundasale } \\ & \text { Ecija }\end{aligned} \quad \begin{aligned} & \text { Nathorn- } \\ & \text { pathom }\end{aligned}$ Waimanalo Mean

1

$2 \quad 3 \quad 4$

5

6

7

8

\begin{tabular}{|c|c|c|c|c|c|c|c|c|c|}
\hline \multicolumn{10}{|l|}{ Sole maize, \%oN } \\
\hline 0 & 613 & 186 & 53 & 125 & 707 & 548 & 513 & 781 & 441 \\
\hline 50 & 861 & 511 & 316 & 235 & 774 & 682 & 578 & 872 & 604 \\
\hline 100 & 1159 & 662 & 577 & 315 & 816 & 604 & 614 & 1128 & 734 \\
\hline \multicolumn{10}{|l|}{ Intercrop, } \\
\hline $\mathbf{0}$ & 696 & 554 & 549 & 280 & 1014 & 666 & 557 & 1028 & 668 \\
\hline 50 & 1105 & 741 & 792 & 306 & 999 & 670 & 609 & 934 & 770 \\
\hline Sole soybean & 300 & 574 & 789 & 301 & 274 & 466 & 340 & 317 & 420 \\
\hline $\operatorname{LSD}(0.05)$ & 178 & 93 & 96 & 88 & 25 & 117 & - & 257 & - \\
\hline \multicolumn{10}{|c|}{ Based on following prices: } \\
\hline \multicolumn{10}{|l|}{ Maize (output) } \\
\hline$(\mathrm{US} \$ / \mathrm{t})$ & 235 & & 30 & 146 & & 17 & 150 & 160 & \\
\hline \multicolumn{10}{|c|}{ Soybean (output) } \\
\hline$(\mathrm{US} \$ / \mathrm{t})$ & 332 & & 0 & 346 & & 92 & 275 & 250 & \\
\hline$N$ (input) (S/t) & 370 & & 35 & 500 & & 60 & 435 & 554 & \\
\hline
\end{tabular}




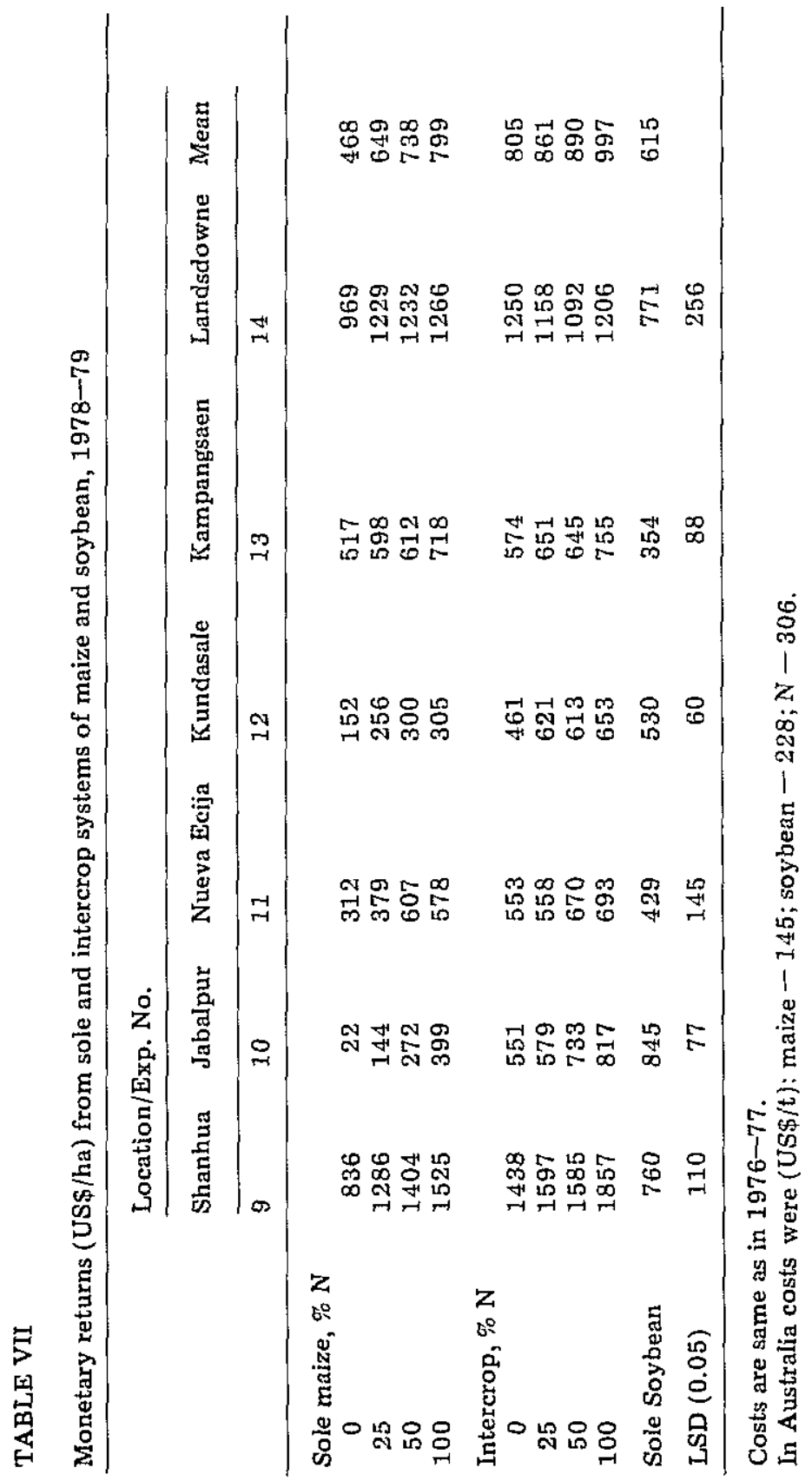


and nitrogen prices indicated in these tables, and assume all other inputs to be the same. However, this assumption is not correct particularly with regard to seed and labour costs because intercropping requires the seed of both crops and additional labour to handle the extra produce. Advan tage of lesser weeds in intercrop plots may offset these costs to a certain extent. A realistic assessment of all these costs would not be possible in small plot experiments.

Taking the average of all 14 experiments, intercropping of maize-soybean was substantially more profitable compared to growing of either crop alone. At zero nitrogen it provided approximately $61 \%$ greater returns than sole maize, and approximately $44 \%$ greater returns than sole soybean. The percentage of additional return with increasing $\mathrm{N}$ application decreased in comparison to sole maize, but increased in comparison to sole soybean. This would indicate that, other things being equal, farmers in developing countries who generally apply little or no nitrogen fertilizer to their maize crops would be much better off intercropping it with soybean than growing it alone. Under conditions of low input use, this would also tend to increase the overall stability of their cropping systems (Rao and Willey, 1980). Even those who normally apply nitrogen and other inputs to their maize, might still benefit by intercropping with soybean. Similarly soybean farmers at most of the locations where the study was conducted may perhaps gain significantly by intercropping with maize compared to growing it alone. Fertilising maize with nitrogen would further improve returns from intercropping although it might have some adverse affect on $\mathrm{N}_{2}$ fixation by soybean. Depending upon agroclimatic conditions prevailing at the time of experimentation, market prices, and the particular genotypes used, the magnitude of benefit from intercropping was seen to vary. Compared to maize, the intercropping benefit was generally higher in 1978-79; compared to soybean, it was generally higher in 1976-77.

While these generalizations appear to be applicable at most locations, some exceptions need to be pointed out. Sole maize provided greater returns than intercropping at all the three $\mathrm{N}$ levels in Australia (Exp. 14). Sole soybean gave higher returns than the unfertilized intercrop treatment in all the three trials in India and in one each in the Philippines (Exp. 4) and Sri Lanka (Exp. 12). In fact, returns from none of the intercrop treatments exceeded those of sole soybean in Philippines and two trials in India. Since soybean prices were higher than maize prices at all locations, small increases in soybean yields resulted in relatively large increases in returns from this crop.

The overall monetary advantage from intercropping agrees well with results of the first INPUTS intercropping study (Ahmed and Gunasena, 1979) and similar other cereal-legume systems studied elsewhere (IRRI, 1976; Francis and Sanders, 1978).

\section{ACKNOWLEDGEMENT}

The following scientists implemented the INPUTS intercropping studies referred to in this paper. Australia: P.G.E. Searle, University of Sydney, N.S.W.; 
China: T.C. Juang, C.C. Chao and M.P. Kuo, National Chung-Hsing University, Taichung, Taiwan; India: S.D. Choubey and R.S. Sharma, J.N. Agricultural University, Jabalpur; Philippines: F.F. Campos, A. Macaso, E.L. Mader and E. Ignacio, Central Luzon State University, Nueva Ecija; Sri Lanka: H.P.M. Gunasena, U.R. Sangakkara, Wickramsinghe and C.S. Weeraratna, University of Peradeniya; Thailand; P. Yingchol, I. Sooksathan and P. Dixit, Kasetsart University, Bangkok; U.S.A. (Hawaii): S. Ahmed and Associates, East-West Center, Honolulu.

\section{REFERENCES}

Agboola, A.A. and Fayemi, A.A.A., 1972. Fixation and excretion of nitrogen by tropical legumes. Agron. J., 64: 409-412.

Ahmed, S., 1974. Recommendations of the planning meeting. In: Proc. Planning and Organization Meeting, INPUTS Project. East-West Center, Honolulu, HI, pp. 1-42.

Ahmed, S. and Gunasena, H.P.M., 1979. N utilization and economics of some intercropped systems in tropical countries. Trop. Agric., 56:115-123.

De, R., Gupta, R.S., Singh, S.P., Pal, M., Singh, S.N., Sharma, R.N. and Kaushik, S.K., 1978. Interplanting maize, sorghum and pearl millet with short duration grain legumes. Indian J. Agric. Sci., 48: 132-137.

Francis, C.A. and Sanders, J.H., 1978. Economic analysis of bean and maize systems: monoculture versus associated cropping. Field Crop Res., 1: 319-335.

Gunasena, H.P.M., Campos, F.F. and Ahmed, S., 1978. Studies on intercropping and utilization of organic residues: A review of INPUTS trial III. In: Proc. Second INPUTS Review Meeting. East-West Center, Honolulu, HI, pp. 99-122.

Giri, G. and De, R., 1979. Effect of proceeding grain legumes on dryland pearl millet in N.W. India. Exp. Agric., 15: 169-172.

IRRI, 1976. Annual Report 1975, International Rice Research Institute, Los Baños, Philippines, pp. 371-373.

Jodha, N.S., 1976. Resource base as determinant of cropping pattern. Symp. Proc. Cropping Systems Research and Development for the Asian Rice Farmer. IRRI, Los Banos, Philippines, pp. 101-126.

Jones, M.J., 1974. Effects of previous crop on yield and nitrogen response of maize at Samaru, Nigeria. Exp. Agric., 10: 273-279.

Lal, R.B., De, R. and Singh, R.K., 1978. Legume contribution to the fertiliser economy in legume-cereal rotations. Indian J. Agric. Sci., 48: 419-424.

Natarajan, M. and Wiley, R.W., 1980. Sorghum--Pigeonpea intercropping and the effects of plant population density, 2. Resource Use. J. Agric. Sci, Camb., 95: 59-65.

Norman, D.W., 1974. Rationalising mixed cropping under indigenous conditions. The example of Northern Nigeria. J. Dev. Stud., 11: 3-21.

Rao, M.R. and Willey, R.W., 1980. Evaluation of yield stability in intercropping: Studies on sorghum/pigeonpea. Exp. Agric., 16: 29-40.

Rao, M.R., Ahmed, S., Gunasena, H.P.M. and Alcantara, A.P., 1979. Multi-locational evaluation of productivity and stability of some cereal/legume intercropping systems: A review of INPUTS trial III. In: Proc. Final INPUTS Review Meeting, East-West Center, Honolulu, HI, pp. 123-160.

Ruschel, A.P., Salali, E. and Vose, P.B., 1979. Nitrogen enrichment of soil and plant by Rhizobium phaseoli-Phaseolus vulgaris symbiosis. Plant Soil, 51:425-429.

Sarena, M.C. and Yadav, D.S., 1975. Multiple cropping with short duration pulses. Indian J. Genet. Plant Breed., 35: 194-208. 
Spratt, E.D. and Chowdhury, S.L., 1978. Improved cropping systems for rainfed agriculture in India. Field Crops Res., 1: 103-126.

Syarifuddin, A., Effendy, S., Ismail, I. and McIntosh, J.H., 1974. Performance of corn, peanut, mungbean and soybean in monoculture and intercrop combinations of corn and legumes in dry season, 1973. Rep. No. 12. Cent. Res. Inst. Agric., Bogor, Indonesia.

Tiwari, B.P. and Bisen, C.R., 1975. Legumes in the crop rotations, mixtures and intercropping. Indian J. Genet. Plant Breed., 35: 282-290.

Trenbath, B.R., 1974. Biomass productivity of mixtures. Adv. Agron., 26: 177-210.

Virtanen, A.I., Van Hausen, S. and Laine, T., 1937. Investigations on the root nodule bacteria of leguminous plants. XX Excretion of nitrogen in associated cultures of legumes and non-legumes. J. Agric. Sci., 27: 585-610.

Wahua, T.A.T. and Miller, D.A., 1978. Relative yield totals and yield components of intercropped sorghum and soybeans. Agron. J., 70: 287-291.

Willey, R.W., 1979. Intercropping - Its importance and research needs. I. Competition and yield advantages. II. Research approaches. Field Crop Abstr., 32: 2-10; 73-81.

Willey, R.W. and Osiru, D.S.O., 1972. Studies on mixtures of maize and beans (Phaseolus vulgaris) with particular reference to plant population. J. Agric. Sci., Camb., 79: $517-529$.

\section{APPENDIX}

Fitted regression for maize yields versus relative $\mathrm{N}$ doses under sole and intercrop systems, $1978-79$

\begin{tabular}{|c|c|c|c|c|}
\hline Exp. No. & Location & System & Equation $^{a}$ & $R^{2}$ \\
\hline \multirow[t]{2}{*}{9} & Shanhua & Sole & $y=3660+74.8 \quad x-0.45 x^{2}$ & 0.93 \\
\hline & & Intercrop & $y=4068+21.8 \quad x$ & 0.86 \\
\hline \multirow[t]{2}{*}{10} & Jabalpur & Sole & $y=120+43.6 x-0.15 x^{2}$ & 0.99 \\
\hline & & Intercrop & $y=128+49.1 x-0.23 x^{2}$ & 0.98 \\
\hline \multirow[t]{2}{*}{11} & Nueva Ecija & Sole & $y=1954+55.2 x-0.33 x^{2}$ & 0.88 \\
\hline & & Intercrop & $y=2497+33.96 x-0.15 x^{2}$ & 0.92 \\
\hline \multirow[t]{2}{*}{12} & Kundasale & Sole & $y=1321+39.89 x-0.26 x^{2}$ & 0.99 \\
\hline & & Intercrop & $y=1698+9.0 \quad x$ & 0.99 \\
\hline \multirow[t]{2}{*}{13} & Kampangsaen & Sole & $y=3522+14.1 \quad x$ & 0.96 \\
\hline & & Intercrop & $y=2101+9.8 x$ & 0.90 \\
\hline \multirow[t]{2}{*}{14} & Lansdowne & Sole & $y=6830+62.4 \quad x-0.42 x^{2}$ & 0.73 \\
\hline & & Intercrop & $y=7595+39.9 x+0.39 x^{2}$ & 0.96 \\
\hline
\end{tabular}

${ }^{\mathrm{a}} y=\operatorname{yield}(\mathrm{kg} / \mathrm{ha}) ; x=$ nitrogen as $\%$ of locally recommended rate. 